\title{
Lyme Disease: What the Neuroradiologist Needs to Know
}

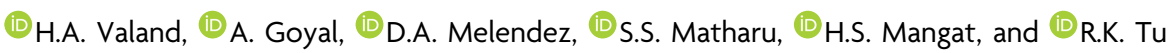

\section{ABSTRACT}

SUMMARY: Lyme disease is the most common tick-borne disease in Canada and the United States, caused by Borrelia burgdorferi, which affects multiple organ systems. Epidemiology, clinical presentation, and neuroimaging findings are reviewed.

\section{What Is Lyme Disease?}

L yme disease, known as Lyme borreliosis, was first described in 1976 by William E. Mast and William M. Burrows in Old Lyme, Connecticut. ${ }^{1}$ It is the most commonly reported vectorborne disease in North America. In the United States, it is caused by Borrelia burgdorferi, a spirochete, closely related clinically to Treponema pallidum (syphilis) and transmitted via the bite of an infected Ixodes tick. ${ }^{2,3}$ Lyme disease is predominantly seen in the mid-Atlantic (primarily New England) and upper Midwest regions (Wisconsin, Minnesota, and Great Lakes region) but is also prevalent in parts of the Pacific coast (Oregon and Washington). ${ }^{4}$ Transmission of this tick-borne zoonosis requires both infected reservoirs in the small mammalian hosts and vector blacklegged ticks. Large mammals like humans are seldom hosts and are mainly affected by nymphal ticks. ${ }^{5}$ The incidence of Lyme disease is approximately 30,000 or 0.5 per 1000 individuals in endemic areas per the Centers for Disease Control and Prevention. ${ }^{2,6}$ However, under-reporting and misclassification are the common drawbacks of any surveillance system. The Centers for Disease Control and Prevention report that highly Lyme endemic states may have considerably higher prevalence than that recorded. ${ }^{7}$

\section{What Are the Clinical Manifestations of Lyme Disease?}

Lyme disease can be classified in 3 stages: early localized (stage 1), early disseminated (stage 2), and late disseminated (stage 3). In

Received August 23, 2019; accepted after revision August 27.

From the American University of Integrative Sciences (H.A.V.), Brampton, Ontario, Canada; George Washington University (A.G., D.A.M.), Washington, DC; The Fischell Department of Bioengineering (S.S.M.), University of Maryland College Park, College Park, Maryland; Germantown Medical Center (H.S.M.), Germantown, Maryland; and Progressive Radiology (R.K.T.), George Washington University, United Medical Center, Washington, DC.

Please address correspondence to Raymond K. Tu, MD, MS, FACR, Progressive Radiology, George Washington University, United Medical Center, 2121 K St NW, Suite 100, Washington, DC 20037; e-mail: Raymond.Tu@progressiveradiology.net; @RayTu10

http://dx.doi.org/10.3174/ajnr.A6301 the early localized stage, erythema migrans is the first and most common sign, seen in up to $70 \%-80 \%$ of the individuals with a tick bite. It appears within 3 to 32 days at the tick bite site and may be asymptomatic, pruritic, or, rarely, painful. In untreated individuals, this lesion can expand up to $61 \mathrm{~cm}$ in diameter. ${ }^{8-13}$ Early dissemination begins within weeks to months after the appearance of erythema migrans. It mainly presents as nonspecific flulike symptoms such as fatigue, malaise, fever, arthralgias, myalgias, and lymphadenopathies. ${ }^{14}$ In addition, $\sim 15 \%$ and $\sim 8 \%$ of patients may develop neurologic and cardiac abnormalities, respectively. The most common neurologic manifestations are lymphocytic meningitis, meningoencephalitis, cranial nerve neuritis, and sensorimotor radiculopathies. ${ }^{15}$ Patients with cardiac involvement mainly have a spectrum of atrioventricular nodal block. ${ }^{16,17}$ In late dissemination, arthritis mainly affecting the large joints (most commonly the knees) is the most common presentation. Because most patients are treated with antibiotics, $<10 \%$ develop arthritis. ${ }^{13,18-20}$ Neurologic deficits such as loss of short-term memory, word amnesia, and progressive loss of multitasking ability with new-onset attention deficit-type symptoms are being increasingly recognized. ${ }^{21}$

\section{How to Diagnose and Treat Lyme Disease}

Lyme disease is diagnosed by combining the clinical examination with serologic testing. The early localized stage of Lyme disease is typically diagnosed with clinical signs and symptoms. ${ }^{22}$

Many physicians use the Centers for Disease Control and Prevention criteria of a Lyme reflex test, measuring the antibody titers to Lyme, and, if positive, performing a western blot to Lyme. $^{23}$ The Centers for Disease Control and Prevention recommend a 2-step quantitative assay to detect antibodies against $B$ burgdorferi. The first step involves the use of an enzyme immunoassay or an indirect immunofluorescence assay. If the result is negative, no further testing is required, but if the test is positive or equivocal, step 2 is performed. Step 2 uses an immunoblotting technique such as a western blot. The test is deemed positive 


\begin{tabular}{|c|c|c|}
\hline Location & Neurologic Presentation & Comments \\
\hline \multirow[t]{3}{*}{ PNS } & Subacute meningitis ${ }^{24}$ & Most common presentation in North America ${ }^{24}$ \\
\hline & Plexus neuritis or mononeuritis multiplex ${ }^{25}$ & $5 \%-10 \%$ cases $^{25}$ \\
\hline & Bannwarth syndrome $e^{15}$ & Uncommon in North America $^{15}$ \\
\hline \multirow[t]{2}{*}{ Cranial nerve } & Facial nerve neuritis ${ }^{26,27}$ & Most commonly involved cranial nerve $e^{26}$ \\
\hline & CN III and $\mathrm{CNV}^{28,29}$ & Few case reports ${ }^{28,29}$ \\
\hline \multirow[t]{3}{*}{ CNS } & $\begin{array}{l}\text { Nonspecific bifrontal white matter T2 } \\
\text { hyperintensity }^{15}\end{array}$ & $50 \%$ of cases with CNS involvement ${ }^{15}$ \\
\hline & Encephalitis-rhombencephalitis pattern likely ${ }^{25}$ & Rare $^{15}$ \\
\hline & Vasculitis $^{15}$ & Rare $^{15}$ \\
\hline Spinal cord & Nonspecific areas of T2 prolongation ${ }^{15}$ & Most common pattern in spinal cord involvement ${ }^{15}$ \\
\hline \multirow[t]{2}{*}{ Ocular } & Conjunctivitis and episcleritis, early stages ${ }^{33,34}$ & $\operatorname{Rare}^{33,34}$ \\
\hline & $\begin{array}{l}\text { Uveitis, orbital myositis, chronic intraocular } \\
\text { inflammation }\end{array}$ & $\operatorname{Rare}^{33,34}$ \\
\hline \multirow[t]{3}{*}{ Pediatric } & Cranial neuritis and meningitis ${ }^{35,36}$ & Most common pediatric neurologic presentation ${ }^{35,36}$ \\
\hline & Peripheral neuritis, myelitis, Bannwarth syndrome ${ }^{37,38}$ & Rare $^{37,38}$ \\
\hline & Prominent Virchow-Robin spaces 37,38 & Less common ${ }^{37,38}$ \\
\hline
\end{tabular}

Note:-CN indicates cranial nerve; PNS, peripheral nervous system.

when both steps are positive. Doxycycline, amoxicillin, or cefuroxime axetil is the first-line treatment, and results in complete resolution of a patient's symptoms. Cases resistant to these antibiotics are treated with macrolides. ${ }^{18}$

\section{What Are the Neuroradiologic Findings in Patients with Lyme Disease?}

There are several neurologic manifestations of Lyme disease. Imaging can be helpful in the assessment of peripheral Lyme disease. A clinical presentation of radiculitis in an endemic region should raise suspicion for the disease. The summary of these neurologic finding is in the Table.

Peripheral Nervous System. In the North American population, the peripheral manifestations are likely an extension of subacute meningitis, such as plexus neuritis or mononeuritis multiplex seen in $5 \%-10 \%$ of cases. ${ }^{24,25}$ Bannwarth syndrome, another complication of Lyme disease less frequently seen in North America, would be indicative of meningoradiculitis. On MR imaging, meningoradiculitis presents as an increased T2 signal of the affected nerve roots, which enhances with gadolinium contrast medium. ${ }^{15}$

Cranial Nerves. Facial nerve involvement is seen in approximately $80 \%$ of the cases, presenting as cranial neuritis. Of these, approximately $25 \%$ of cases show bilaterality. On MR imaging, enhancement of the affected nerve can be seen. ${ }^{26,27}$ Cranial nerve III and V involvement has also been reported. ${ }^{28,29}$ There still remains a lack of specificity to diagnose Lyme disease on imaging alone. In the clinical setting, attention should be paid to asymmetry or marked intensity of enhancement in the course of facial nerve geniculate ganglion and beyond. Enhancement of the typically nonenhancing facial nerve segments proximal to geniculate ganglion should also raise the suspicion. ${ }^{25}$

Central Nervous System. Half of the affected patients with CNS involvement show nonspecific abnormal signal in the frontal lobe white matter. This signal may persist even after clinical resolution post-antibiotic treatment. ${ }^{15}$ On a molecular level, the immune response to Lyme disease and MS has been found to be relatively similar, yet T-cell lines demonstrate only weak cross-reactivity between myelin basic protein and $B$ burgdorferi. ${ }^{30}$ On magnetization transfer and DTI sequences, the presence of occult brain and cervical cord pathology in otherwise normal white matter would be more indicative of MS. ${ }^{31}$ Progression of CNS involvement can lead to encephalitis. Although there is no specific pattern of involvement, there have been a few cases showing a rhombencephalitis pattern of involvement affecting the brain stem and cerebellum, though this pattern of involvement can also be seen in tubercular or Listeria infection. ${ }^{25}$ There have been a few case reports of Lyme-related vasculitis and subsequent strokelike symptoms. Lyme disease rarely affects the spinal cord. ${ }^{15}$ In affected patients, it is characterized by diffuse or multifocal areas of T2 prolongation. In contrast to MS, there are no occult lesions on magnetization-transfer images. Postcontrast images are helpful to demonstrate any associated nerve root enhancement. ${ }^{31,32}$

Ocular. The most common orbital/ocular manifestations of Lyme disease in the early stages are conjunctivitis, episcleritis, and subtle keratitis. Later stages may present as uveitis, orbital myositis, or chronic intraocular inflammation presenting with floaters and photophobia. Later stages of chronic intraocular inflammation can mimic orbital pseudotumor (due to raised intracranial pressure) or lymphoma. ${ }^{33,34}$ The clinical and imaging manifestations of orbital myositis in Lyme disease closely mimics those orbital pseudotumor; lymphoma and thyroid dysorbitopathy are possible differential diagnoses. ${ }^{15,33}$

Pediatric Patients. Facial neuritis and meningitis are the most common neurologic presentations in the pediatric population. ${ }^{35,36}$ Peripheral neuritis, myelitis, and Bannworth syndrome are rare in children. The overall clinical course is milder and shorter compared with adults. Affected pediatric patients may show prominent VirchowRobin spaces and $\mathrm{T} 2$ hyperintense lesions. ${ }^{37,38}$

\section{CONCLUSIONS}

This Clinical Vignette reviews the most common tickborne disease in Canada and the United States and important neuroradiologic 
findings. Heightened interpretive sensitivity to the myriad nonspecific imaging findings may provide critical clinical information to diagnose and monitor Borrelia burgdorferi infection.

\section{REFERENCES}

1. Mast WE, Burrows WM. Erythema Chronicum Migrans in the United States. JAMA 1976;236:859-60 CrossRef Medline

2. Shapiro ED. Borrelia burgdorferi (Lyme disease). Pediatr Rev 2014;35:500-09 CrossRef Medline

3. Centers for Disease Control and Prevention. Lyme Disease. https:// www.cdc.gov/lyme/index.html. Last reviewed June 3, 2019. Accessed June 25, 2019

4. Schwartz AM, Hinckley AF, Mead PS, et al. Surveillance for Lyme disease: United States, 2008-2015. Surveillance Summaries 2017;66:1-12 CrossRef

5. National Collaborating Centre for Infectious Diseases. ARCHIVED: Lyme Disease in Canada. An Update on the Epidemiology. https:// nccid.ca/publications/lyme-disease-in-canada-an-update-on-theepidemiology/. Published April 2014. Accessed June 25, 2019

6. Centers for Disease Control and Prevention. Data and Surveillance. https://www.cdc.gov/lyme/datasurveillance/index.html. Accessed June 25, 2019

7. Centers for Disease Control and Prevention. Lyme disease surveillance and available data. https://www.cdc.gov/lyme/stats/ survfaq.html. Accessed August 19, 2019

8. Bush LM, Perez MT. Lyme Disease: Infectious Diseases. Merck Manuals Professional Edition. https://www.merckmanuals.com/ professional/infectious-diseases/spirochetes/lyme-disease. Accessed June 25, 2019.

9. Shapiro ED. Lyme disease. N Engl J Med 2014;371:683-84 CrossRef Medline

10. Tibbles CD, Edlow JA. Does this patient have erythema migrans? JAMA 2007;297:2617-27 CrossRef Medline

11. Steere AC, Sikand VK. The presenting manifestations of Lyme disease and the outcomes of treatment. N Engl J Med 2003;348:247274 CrossRef Medline

12. Nadelman RB, Nowakowski J, Forseter G, et al. The clinical spectrum of early Lyme borreliosis in patients with culture confirmed erythema migrans. Am J Med 1996;100:502-08 CrossRef Medline

13. Smith RP, Schoen RT, Rahn DW, et al. Clinical characteristics and treatment outcome of early Lyme disease in patients with microbiologically confirmed erythema migrans. Ann Intern Med 2002; 136:421 CrossRef Medline

14. Wormser GP. Early Lyme disease. N Engl J Med 2006;354:2794-2801 CrossRef Medline

15. Hildenbrand P, Craven D, Jones R, et al. Lyme neuroborreliosis: manifestations of a rapidly emerging zoonosis. AJNR Am J Neuroradiol 2009;30:1079-87 CrossRef Medline

16. Steere AC. Lyme disease. N Engl J Med 1989;321:586-96 CrossRef Medline

17. Forrester JD, Meiman J, Mullins J, et al. Notes from the field: update on Lyme carditis, groups at high risk, and frequency of associated sudden cardiac death-United States. MMWR Morb Mortal Wkly Rep 2014;63:982-83 Medline

18. Wormser GP, Dattwyler RJ, Shapiro ED, et al. The clinical assessment, treatment, and prevention of Lyme disease, human Granulocytic Anaplasmosis, and Babesiosis: Clinical Practice
Guidelines by the Infectious Diseases Society of America. Clin Infect Dis 2006;43:1089-1134 CrossRef Medline

19. Stanek G, Wormser GP, Gray J, et al. Lyme borreliosis. Lancet 2012;379:461-73 CrossRef Medline

20. Wormser GP, McKenna D, Carlin J, et al. Brief communication: hematogenous dissemination in early Lyme disease. Ann Intern Med 2005;142:751 CrossRef Medline

21. Bransfield RC. Neuropsychiatric Lyme borreliosis: an overview with a focus on a specialty psychiatrist's clinical practice. Healthcare (Basel) 2018;6:104 CrossRef Medline

22. Steere A. Lyme disease. N Engl J Med 2001;345:115-25 CrossRef Medline

23. Centers for Disease Control and Prevention. Lyme Disease. Laboratory testing. https://www.cdc.gov/lyme/diagnosistesting/ index.html. Accessed October 11, 2019

24. Schwenkenbecher P, Pul R, Wurster U, et al. Common and uncommon neurological manifestations of neuroborreliosis leading to hospitalization. BMC Infect Dis 2017;17:90 CrossRef Medline

25. Lindland ES, Solheim AM, Andreassen S, et al. Imaging in Lyme neuroborreliosis. Insights Imaging 2018;9:833-44 CrossRef Medline

26. Halperin JJ. Nervous system Lyme disease. Infect Dis Clin North Am 2015;29:241-53 CrossRef Medline

27. Strle F, Stanek G. Clinical manifestations and diagnosis of Lyme borreliosis: current problems in dermatology Lyme Borreliosis. Curr Probl Dermatol 2009;37:51-110 CrossRef Medline

28. Savas R, Sommer A, Gueckel F, et al. Isolated oculomotor nerve paralysis in Lyme disease: MRI. Neuroradiology 1997;39:139-41 CrossRef Medline

29. Nelson JA, Wolf MD, Yuh WT, et al. Cranial nerve involvement with Lyme borreliosis demonstrated by magnetic resonance imaging. Neurology 1992;42:671-71 CrossRef Medline

30. Pohl-Koppe A, Logigian EL, Steere AC, et al. Reactivity of Borrelia burgdorferi and myelin basic protein-specific $T$-cells is not observed in borrelial encephalomyelitis. Cell Immunol 1999;194: 118-23 CrossRef Medline

31. Agosta F, Rocca MA, Benedetti B, et al. MR imaging assessment of brain and cervical cord damage in patients with neuroborreliosis. AJNR Am J Neuroradiol 2006;27:892-94 Medline

32. Hattingen E, Weidauer S, Kieslich $M$, et al. MR imaging in neuroborreliosis of the cervical spinal cord. Eur Radiology 2004;14:207275 CrossRef Medline

33. Lesser RL. Ocular manifestations of Lyme disease. Am J Med 1995;98:60S CrossRef

34. Zagorski Z, Biziorek B, et al. Ophthalmic manifestations in Lyme borreliosis [in Polish]. Przegl Epidemiol 2002;56(Suppl 1):85-90 Medline

35. Shapiro E, Seltzer E. Lyme disease in children. Semin Neurol 1997;17:39-44 CrossRef Medline

36. Belman AL, Iyer M, Coyle PK, et al. Neurologic manifestations in children with North American Lyme disease. Neurology 1993;43: 2609-14 CrossRef Medline

37. Belman AL, Coyle PK, Roque C, et al. MRI findings in children infected by Borrelia burgdorferi. Pediatr Neurol 1992;8:428-31 CrossRef Medline

38. Vanzieleghem B, Lemmerling $M$, Carton D, et al. Lyme disease in a child presenting with bilateral facial nerve palsy: MRI findings and review of the literature. Neuroradiology 1998;40:739-42 CrossRef Medline 